\title{
CONTAMINATION POTENTIAL OF SPECIFIC IONS IN SOIL TREATED WITH REJECT BRINE FROM DESALINATION PLANTS ${ }^{1}$
}

\author{
ANDLER MILTON PAIVA DE OLIVEIRA ${ }^{2}$, CEZAR AUGUSTO MEDEIROS REBOUÇAS ${ }^{2}$, NILDO DA SILVA \\ DIAS $^{2 *}$, JEANE CRUZ PORTELA ${ }^{2}$, ADRIANA ARAÚJO DINIZ ${ }^{2}$
}

\begin{abstract}
Percolation columns constructed in the Laboratory can predict the degree of contamination in soil due to reject brine disposal and can be a tool for reducing environmental impacts. This study aim to evaluate the mobilization of ions in reject brine from desalination process by reverse osmosis. The mobilization of the contaminant ions in the saline waste was studied in glass percolation columns, which were filled with soil of contrasting textures (eutrophic CAMBISOL, typic dystrophic Red OXISOL, ENTISOL Quartzipsamment). Experiments ware repeated three times each, and the initial and final concentrations of the ion contaminants were analyzed. The pollution potential of this wastewater was determined by the retardation factor and dispersion-diffusion coefficient of $\mathrm{K}^{+}, \mathrm{Cl}^{-}$and $\mathrm{Na}^{+}$for each studied soil. The differences in the displacement curves of the ions present in the saline waste among various soil types were analyzed. The Entisol Quartzipsamment showed a higher forward speed of the ions $\mathrm{K}^{+}$and $\mathrm{Cl}^{-}$(greater retardation factor, i.e., greater power of the subsurface contamination for these ions). In typic dystrophic Red OXISOL, the ions move with greater ease and therefore produced greater groundwater contamination. In eutrophic CAMBISOL, the low coefficient of diffusion-dispersion in all ions was evaluated (i.e., reduced ion mobility is directly influenced by their exchangeable levels).
\end{abstract}

Keywords: Semi-arid. Water reuse. Reverse osmosis.

\section{POTENCIAL CONTAMINANTE DE ÍONS ESPECÍFICOS EM SOLOS TRATADOS COM REJEITO DE DESSALINIZADORES}

RESUMO - As colunas de percolação, construídas em Laboratório, podem predizer o grau de contaminação nos solos receptores do rejeito da dessalinização da água, podendo ser uma ferramenta de prevenção a impactos ambientais. O presente trabalho objetivou avaliar a mobilização de íons presentes nos rejeitos salinos proveniente do processo de dessalinização das águas salobras. A mobilização dos íons contaminante no rejeito salino foi estudada em colunas de percolação construída de vidro, as quais foram preenchidas com solos de textura contrastante (CAMBISSOLO Eutrófico, LATOSSOLO Vermelho distrófico, NEOSSOLO Quartzarênico), com três repetições cada, sendo analisada as suas concentrações inicial e final dos íons contaminantes. Para a avaliação do potencial de poluição deste resíduo foi determinado o fator de retardamento e o coeficiente de difusão-dispersão dos íons $\mathrm{K}^{+}, \mathrm{Cl}^{-}$e $\mathrm{Na}^{+}$para cada solo estudado. Houve diferença das curvas de deslocamento dos íons presentes no rejeito salino entre os tipos de solos. O Neossolo apresentou maior velocidade de avanço dos íons $\mathrm{K}^{+}$e $\mathrm{Cl}^{-}$, ou seja, maior poder de contaminação em subsuperfície para estes íons. No Latossolo, os íons deslocam-se com maior facilidade e, portanto, maior facilidade de contaminação do lençol freático. No Cambissolo houve baixos valores de coeficiente de difusão-dispersão em todos os íons avaliados, ou seja, menor mobilidade dos íons, sendo diretamente influenciados pelos respectivos teores trocáveis.

Palavras-chave: Semiárido. Reuso de água. Osmose reversa.

\footnotetext{
*Corresponding Author

${ }^{1}$ Received for publication in $07 / 31 / 2014$; accepted in 04/22/2016.

Extracted from the first author's Master's dissertation, funded by CNPq.

${ }^{2}$ Department of Environmental Sciences and Technological, Universidade Federal Rural do Semi-Árido, Mossoró, RN, Brazil; andlermilton@hotmail.com, cezar_augusto1992@hotmail.com,nildo@ufersa.edu.br, jeaneportela@ufersa.edu.br, adriana@ufersa.edu.br.
} 


\section{INTRODUCTION}

In the semi-arid region of Brazil, a major challenge for the local population is the contamination of the water supply (GOMES et al., 2011; SOUSA NETO et al., 2011), which is used for human and animal consumption and food production, and thus impacts the entire production chain (OLIVEIRA, 2012; HESPANHOL, 2002). The capitation of groundwater is regarded as a viable alternative mode of access to this resource for the population (OLIVEIRA, 2012; COSME et al., 2011; SANTOS et al., 2010a); however, groundwater use in this region is restricted due to the high-salinity (SILVA et al., 2011; OLIVEIRA et al., 2007; AYRES; WESTCOT, 1999). According to the Associação Brasileira de Águas Subterrânas (ABAS, 2003 ), approximately $80 \%$ of the northeastern region is predominantly composed of crystalline rocks and approximately $20 \%$ consists of sedimentary rocks that may present a high salt concentration.

In the semi-arid region the main aquifers are arranged in sedimentary formations, e.g., Jandaíra aquifer, which has restrictions on use due to the high degree of salinization (MEDEIROS et al. 2003; ABAS, 2003). In such cases, due to the high salinity, water is pre-treated by a reverse osmosis desalination process (OLIVEIRA, 2012; DIAS et al, 2011b). This technique is very commonly used in arid and semiarid regions (SANTOS et al. 2010c; VOUTCHKOV, 2004). The reverse osmosis process is used in the desalination of brackish water (SCHNEIDER; TSUTIYA, 2001), however, in addition to generating high quality water, this desalination process also generates waste products (approximately 50\% of the processed water) (DIAS et al., 2011a; SOARES et al., 2006; PORTO; AMORIM; SILVA JUNIOR, 2001), which have a higher salinity than that of the water collected in the aquifer.

Saline wastewater from from desalination process by reverse osmosis is often inappropriately disposed of in soil and water sources, resulting in salinization and subsequent damaging of the physical and chemical quality of these resources (SOUSA NETO et al., 2011; DIAS et al., 2010). According Santos et al. (2011) and Silva et al. (2008), the improper disposal of saline waste can severely impact the environment and negatively impact local quality of life and the economy.

The study of the ion dynamics occurring in the reject brine from desalination plants discarded into the soil is extremely important for the evaluation of the potential contamination of both soil and water sources. We must consider that the ions present in this water will behave differently depending on the soil type. Therefore, the present study aims to evaluate the displacement of the contaminant ions in the saline tailings water using percolation columns with different soils in order to determine the pollution potential of this water.

\section{MATERIAL AND METHODS}

The percolation column is a tool used to simulate the behavior of solute movement through soil. This is based on the principle of accommodation of previously treated soil with wellknown physical characteristics, followed by the application of the solution to be studied in the soil and subsequently by infiltration and the collection of the predetermined pore volumes. Importantly, the dimensions of the column are measured in order to calculate the pore volume to be collected.

The experiment was carried out at the Rural Federal University of Semi-Árido (UFERSA) Soil Physics Laboratory. Three soil types from different regions of Baraúna - Natal, State of Rio Grande do Norte, were used. The classification of the soils and their locations are shown in Table 1.

Table 1. Studied soil classifications and locations.

\begin{tabular}{cc}
\hline Classification (SiBCS) & Location $(\mathrm{RN})$ \\
\hline eutrophic CAMBISOL & Baraúna \\
typic dystrophic Red OXISOL & Alagoinha, Mossoró \\
Entisol Quartzipsamment & Boa Fé, Mossoró \\
\hline
\end{tabular}

SiBCS -Brazilian Soil Classification System.

Each percolation column was filled with one type of soil sample, and the experiment was performed in triplicate, producing a total of nine experimental units. The soil was filled to a height of $0.20 \mathrm{~m}$ within the percolation column, with a crushed stone layer of $0.005 \mathrm{~m}(1.00$ to $0.50 \mathrm{~mm})$ as a base to facilitate drainage and to prevent loss of soil material (Fig. 1).
The soil was collected in a zigzag pattern for the percolation study to ensure that representative samples were obtained from each site. The samples were collected from the layeres soil profile $0-20 \mathrm{~cm}$. Soil samples with deformed structures were collected for physical and chemical analyses and were collected from the air-dried fine earth fraction (ADFE). For the physical analyses of soil bulk density and total porosity, samples with un-deformed 
structures were collected using Uhland auger and volumetric rings with dimensions of $5 \mathrm{~cm}$ in height and $5 \mathrm{~cm}$ in diameter. The physical and chemical analyses followed the recommendations outlined in the Manual of Soil Analysis Methods (EMBRAPA, 1997).

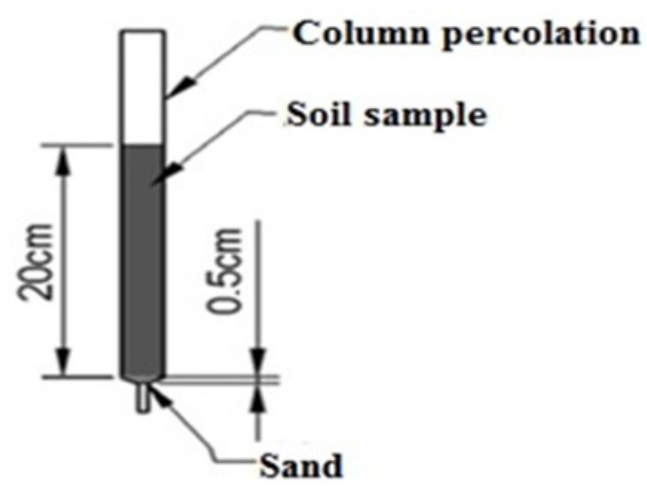

Figure 1. Schematic diagram of the percolation column installation showing the assembling and filling of the soil.

The evaluated physical parameters included: particle size, which was assessed by the pipette method employing sodium hex ametaphosphate as a chemical dispersant; solid density $\left(\rho_{\mathrm{s}}\right)$, which was assessed by the volumetric flask method; soil density $(\rho)$, which was assessed by the volumetric ring method; and total porosity $(\alpha)$, as described in
Equation 1.

$$
\alpha=\left(1-\frac{\rho}{\rho_{\mathrm{s}}}\right) * 100
$$

Where $\alpha$ is the total calculated porosity (\%), $\rho$ is the soil density, $\left(\mathrm{kg} \mathrm{dm}^{-3}\right)$, and $\rho_{\mathrm{s}}$ is the solid density $\left(\mathrm{kg} \mathrm{dm}^{-3}\right)$. Results are shown in Table 2 .

Table 2. Distribution of particle size, texture classification, soil density $(\rho)$, solid density $\left(\rho_{s}\right)$, and calculated total porosity $(\alpha)$.

\begin{tabular}{cccccccc}
\hline \multirow{2}{*}{ Soil } & \multicolumn{3}{c}{ Particle size distribution } & & & \\
\cline { 2 - 4 } & Sand & Silt & Clay & & & & \\
& & & & & \\
& & $\left(\mathrm{g} \mathrm{kg}^{-1}\right)$ & & & $\left(\mathrm{kg} \mathrm{dm}^{-3}\right)$ & $(\%)$ \\
Eutrophic Cambisol & 662.80 & 96.50 & 240.70 & Frank-clay-sandy & 1.46 & 2.47 & 40.89 \\
typic dystrophic Red Oxisol & 823.80 & 28.40 & 147.80 & Sand-frank & 1.68 & 2.51 & 33.07 \\
Entisol Quartzipsamment & 897.50 & 21.60 & 80.90 & Sand & 1.64 & 2.59 & 36.68 \\
\hline
\end{tabular}

SBCS - Brazilian Society for Soil Science; $\rho$ - soil density; $\rho_{\mathrm{s}}$ - solid density; $\alpha$ - calculated total porosity.

Measured chemical characteristics were: $\mathrm{pH}$ of the water at a ratio of $1: 2.5$, electrical conductivity of the saturated soil-paste extract $\left(\mathrm{EC}_{\mathrm{s}}\right)$, exchangeable calcium $\left(\mathrm{Ca}^{2+}\right)$ and magnesium $\left(\mathrm{Mg}^{2+}\right)$ - as assessed by employing complexometry after extraction with $\mathrm{KCl} 1 \mathrm{~mol} \mathrm{~L}^{-1}$, exchangeable aluminum $\left(\mathrm{Al}^{3+}\right)$ - as assessed by extraction with $\mathrm{KCl} 1 \mathrm{~mol} \mathrm{~L}^{-1}$ and titrated with $\mathrm{NaOH} 0.025 \mathrm{~mol} \mathrm{~L}^{-1}$, available phosphorus (P), sodium $\left(\mathrm{Na}^{+}\right)$and potassium $\left(\mathrm{K}^{+}\right)$- extracted in Mehlich-1 and determined by spectrophotometry visualization (P) and detected by flame photometry $\left(\mathrm{Na}^{+}\right.$and $\left.\mathrm{K}^{+}\right)$, the potential acidity $(\mathrm{H}+\mathrm{Al})$ - quantified by titration with $0.025 \mathrm{~mol} \mathrm{~L}^{-1} \mathrm{NaOH}$ after extraction with calcium acetate at a concentration of $0.5 \mathrm{~mol} \mathrm{~L}^{-1}$ with a $\mathrm{pH}$ of 7.0 and, soil organic matter (SOM) - as assessed by $0.005 \mathrm{~mol} \mathrm{~L}^{-1}$ ferrous ammonium sulfate titration after being heated in a uniform plate with $0.02 \mathrm{~mol} \mathrm{~L}^{-1}$ potassium dichromate. The results are shown in Table 3.

Table 3. Characterization of soil chemical properties.

\begin{tabular}{lcccccccccc}
\hline \multicolumn{1}{c}{ Soil } & $\mathrm{pH}$ & $\mathrm{EC}_{\mathrm{s}}$ & $\mathrm{SOM}$ & $\mathrm{P}$ & $\mathrm{K}^{+}$ & $\mathrm{Na}^{+}$ & $\mathrm{Ca}^{2+}$ & $\mathrm{Mg}^{2+}$ & $\mathrm{Al}^{3+}$ & $(\mathrm{H}+\mathrm{Al})$ \\
\hline & $($ water $)$ & $\left(\mathrm{dS} \mathrm{m}^{-1}\right)$ & $\left(\mathrm{g} \mathrm{kg}^{-1}\right)$ & $\ldots \ldots \ldots\left(\mathrm{mg} \mathrm{dm}^{-3}\right)$ & $\ldots \ldots \ldots \ldots$ & $\ldots \ldots \ldots \ldots \ldots\left(\mathrm{cmol}_{\mathrm{c}} \mathrm{dm}^{-3}\right) \ldots \ldots$ \\
Eutrophic Cambisol & 7.46 & 0.06 & 10.99 & 2.28 & 166.87 & 21.74 & 6.24 & 2.50 & 0.00 & 8.58 \\
typic dystrophic Red Oxisol & 5.35 & 0.06 & 8.80 & 1.41 & 35.29 & 15.96 & 0.98 & 0.49 & 0.06 & 3.82 \\
Entisol Quartzipsamment & 6.00 & 0.06 & 6.51 & 9.10 & 55.24 & 17.66 & 1.55 & 1.17 & 0.02 & 0.33 \\
\hline
\end{tabular}

$\mathrm{pH}$ - hydrogen potential, $\mathrm{EC}_{\mathrm{s}}$ - electrical conductivity of the saturated soil-paste extract, SOM - soil organic matter, $\mathrm{P}$ available phosphorus, $\mathrm{K}^{+}$- potassium, $\mathrm{Na}^{+}$- sodium, $\mathrm{Ca}^{2+}$ - calcium, $\mathrm{Mg}^{2+}$ - magnesium, $\mathrm{Al}^{3+}$ - aluminum and, $(\mathrm{H}+\mathrm{Al})$ potential acidity. 
The reject brine sampling was carried out in the Boa Fé rural community in Mossoró, Rio Grande do Norte State, Brazil. This community has a desalination plant by reverse osmosis that provides treated water to the population and, as a result of the desalination process, also generates reject brine.
The chemical characteristics of the saline tailings measured in this study were $\mathrm{pH}$, electric conductivity $\left(\mathrm{EC}_{\mathrm{w}}\right)$, potassium $\left(\mathrm{K}^{+}\right)$, sodium $\left(\mathrm{Na}^{+}\right)$, calcium $\left(\mathrm{Ca}^{2+}\right)$, magnesium $\left(\mathrm{Mg}^{2+}\right)$, chloride $\left(\mathrm{Cl}^{-}\right)$, and the sodium adsorption ratio (SAR), which was determined according to the methodology described by Tedesco et al.(1995) (Table 4).

Table 4. Reject brine chemical analysis.

\begin{tabular}{cccccccc}
\hline $\mathrm{pH}$ & $\mathrm{EC}_{\mathrm{w}}$ & $\mathrm{K}^{+}$ & $\mathrm{Na}^{+}$ & $\mathrm{Ca}^{2+}$ & $\mathrm{Mg}^{2+}$ & $\mathrm{Cl}^{-}$ & $\mathrm{SAR}$ \\
\hline & $\left(\mathrm{dS} \mathrm{m}^{-1}\right)$ & \multicolumn{5}{c}{$\left(\mathrm{mmol}_{\mathrm{c}} \mathrm{L}^{-1}\right)$} \\
7.42 & 10.15 & 0.80 & 4.11 & 31.49 & 25.21 & 89.70 & $\left(\mathrm{mmol}_{\mathrm{c}} \mathrm{L}^{-1}\right)^{1 / 2}$ \\
\hline
\end{tabular}

$\mathrm{pH}$ - hydrogen potential; $\mathrm{EC}_{\mathrm{w}}$ - electrical conductivity; $\mathrm{K}^{+}$- potassium; $\mathrm{Na}^{+}$- sodium; $\mathrm{Ca}^{2+}$ - calcium; $\mathrm{Mg}^{2+}$ magnesium; $\mathrm{Cl}^{-}$- chloride; SAR - sodium adsorption ratio.

According to the $\mathrm{EC}_{\mathrm{w}}$ data, the water is highly brackish $\left(\mathrm{EC}_{\mathrm{w}}=10.15 \mathrm{dS} \mathrm{m} \mathrm{m}^{-1}\right)$, and it appears, according to the guidelines proposed by Ayres \& Westcot (1999), that the reject brine have a severe use restrictions due to salinity risks $\left(\mathrm{EC}_{\mathrm{w}}>3.00 \mathrm{dS} \mathrm{m}\right.$ $\left.{ }^{-1}\right)$. Additionally, according to the same authors, the chloride ion has a severe degree of restriction $\left(\mathrm{Cl}^{-}>\right.$ $10 \mathrm{mmol}_{\mathrm{c}} \mathrm{L}^{-1}$ ).

To fill the percolation columns, volume was calculated using the dimensions of $390 \mathrm{~mm}$ height and $34.52 \mathrm{~mm}$ diameter. The volume was calculated as the product of the area and the height of the percolation column (Eq. 2):

$$
\mathrm{Vt}=\frac{\pi \mathrm{D}^{2}}{4} * \mathrm{~h}
$$

Where $\mathrm{Vt}$ is the percolation column total volume $\left(\mathrm{cm}^{3}\right)$, D is the percolation column internal diameter $(\mathrm{cm})$, and $\mathrm{h}$ is the percolation column height $(\mathrm{cm})$.

A grid was placed at the bottom of the column to serve as a layer to prevent the passage of gravel and soil. Approximately $13 \mathrm{~g}$ of fine gravel was placed at the bottom of the column. After adding the gravel, a mesh was placed on top and then a 10 $\mathrm{cm}$ additional layer of gravel was added. One-third of the column was left unfilled to serve as space for the excess solution that remains above ground. Thus, the following soil was added: $-\mathrm{hsc}=2 / 3 \mathrm{~h}-1.0=$ $25.0 \mathrm{~cm}$. Therefore, using Equation 1 and substituting in the new height, we obtain the Equation 3:

$$
\mathrm{Vts}=\frac{\pi \mathrm{D}^{2}}{4} * \mathrm{hs}
$$

Where Vts is soil total volume to be placed in column $\left(\mathrm{cm}^{3}\right)$, D is the column internal diameter $(\mathrm{cm})$, and hs is soil height in the column $(\mathrm{cm})$.

The soil was weighed to determine a bulk density measure and for total porosity calculations. Before filling the soil, the gravel layer was moistened to facilitate packing of the soil, thus reducing the chance of the soil passing the gravel.

After allowing the soil to set, Mariotte flasks, 2-1 PET bottles, rubber covers, micro tubes serving as capillaries, and hose connections were used to feed the solutions to the systems. The Mariotte flasks were left behind the percolation columns, supported by a wooden board. Before mounting, the rubber covers were pierced at two sites for the insertion of microtubules, and then the rubber covers were connected to the bottles. One end of the hose was connected to one of the microtubules, and the other end was connected to the percolation column. The bottles served to control the output supplied to the system used to fill the column with the tailing to be studied.

The pore volume $\left(\mathrm{V}_{0}\right)$ within each column for the three soil types were determined using the relation described in Equation 4.

$$
\mathrm{V}_{0}=\mathrm{V}_{\mathrm{T}} \mathrm{f}=\pi \mathrm{r}^{2} \mathrm{~h}\left(1-\frac{\rho}{\rho_{\mathrm{S}}}\right)
$$

Where $\mathrm{V}_{0}$ is pores volume $\left(\mathrm{cm}^{3}\right), \mathrm{V}_{\mathrm{T}}$ is total soil volume in the column $\left(\mathrm{cm}^{3}\right)$, $\mathrm{f}$ is the total porosity $\left(\mathrm{dm}^{3} \mathrm{dm}^{-3}\right), \mathrm{r}$ is the column internal radius $(\mathrm{cm}), \mathrm{h}$ is the soil height in the column $(20 \mathrm{~cm}), \rho$ is the soil density $\left(\mathrm{g} \mathrm{cm}^{-3}\right)$, and $\rho_{\mathrm{s}}$ is the solid density $\left(\mathrm{g} \mathrm{cm}^{-3}\right)$.

Before performing the experiments, the soil was saturated with distilled water. This procedure filled all of the pore spaces and could thus be used as a proxy for the displacement of the study fluid to be used.

The tests were performed in triplicate for each soil type. The soil was saturated and the volume to be collected was fixed $(10 \mathrm{~mL})$ because it is known that water infiltration into the soil is very slow. Thus, with a fixed volume, the collection time was measured and the output and soil flux were calculated (Table 5). 
Table 5. Results from each soil output test.

\begin{tabular}{cccc}
\hline Soil & Time & Output & Flow \\
\hline & $(\min )$ & $\left(\mathrm{cm}^{3} \mathrm{~min}^{-1}\right)$ & $\left(\mathrm{cm} \mathrm{h}^{-1}\right)$ \\
Eutrophic Cambisol & 8.57 & 1.20 & 0.19 \\
typic dystrophic Red Oxisol & 1.68 & 6.20 & 1.46 \\
Entisol Quartzipsamment & 4.60 & 2.19 & 0.39 \\
\hline
\end{tabular}

The output was obtained from the relation between the collected volume $(10 \mathrm{~mL})$ and the total fluid percolation time into the soil, as described in Equation 5.

$$
\mathrm{Q}=\frac{\mathrm{V}}{\mathrm{t}}
$$

Where $\mathrm{Q}$ is the system output, $\left(\mathrm{cm}^{3} \mathrm{~min}^{-1}\right), \mathrm{V}$ is the collected fluid volume $(10 \mathrm{~mL})$, and $\mathrm{t}$ is the total fluid percolation time in the soil ( $\mathrm{min}$ ). The flow was then calculated using the relationship described in Equation 6.

$$
\mathrm{q}=\frac{\mathrm{Q}}{\mathrm{A}}
$$

Where $\mathrm{q}$ the flow $\left(\mathrm{cm} \mathrm{h}^{-1}\right), \mathrm{Q}$ is the system output $\left(\mathrm{cm}^{3} \mathrm{~min}^{-1}\right)$, and $\mathrm{A}$ is the column cross section $\left(\mathrm{cm}^{2}\right)$.

After the saturation process, soil washing was performed leaving the system open for the study solution to infiltrate into the ground and percolate. This step stopped when the collected solution presented a low electrical conductivity. In each collected volume, a conductivity meter was used to determine the electrical conductivity of the solution, thus ensuring the closest value to zero.

A hose was used to constantly supply the system and ensure a constant flow of the saline tailing solution into the soil. The procedure was terminated when the electric conductivity of the collected solution was approximately equal to the used reject brine.

The solution volume to be collected was fixed $(50 \mathrm{~mL})$ during the experimental data collection. Therefore, using the collected volume and the soil column volume, the pore volume for each volume to be collected was calculated.

The pore volume for each of the studied soils was determined using Equation 7, which refers to the relation between the total volume of the soil column and the total collected volume:

$$
\mathrm{np}=\frac{\mathrm{v}_{0}}{\mathrm{~V}_{\mathrm{T}}}
$$

Where $\mathrm{np}$ is the pore number, $\mathrm{V}_{0}$ is the total soil volume in the column $\left(\mathrm{cm}^{3}\right)$, and $\mathrm{V}_{\mathrm{T}}$ is the total collected volume $\left(\mathrm{cm}^{3}\right)$.
Each solution sample was placed on properly identified collectors with each soil, repetition, and pore volume to be collected. All collectors were closed and sealed with adhesive tape to prevent possible loss. Then, the samples were allocated and stored in a freezer at an optimum temperature to avoid evaporative loss.

After reaching a permanent outflow in the percolation column, a five-pore volume pulse of displacing solution was applied, collecting effluent fractions with a 0.5 -pore volume, which were placed in plastic containers with pressurized covers and frozen for further analysis. The $\mathrm{K}, \mathrm{Na}$ and $\mathrm{Cl}$ concentrations in the effluent were determined $(\mathrm{C})$. The relative concentrations $\left(\mathrm{C} / \mathrm{C}_{0}\right)$ for each ion were calculated, $\mathrm{C}_{0}$ being the concentration in the shifter fluid.

The retardation factor $(\mathrm{R})$ and the dispersiondiffusion coefficient (D) values were obtained from the DISP program (BORGES JÚNIOR; FERREIRA, 2006). As input data for the program, the following variables were used: flow, total porosity, soil column height $(20 \mathrm{~cm})$, pore volume, and experimental relative concentration.

The output variables were the $\mathrm{R}$ and $\mathrm{D}$ values, which were analyzed by the Tukey test at a $5 \%$ probability $(\mathrm{P}<0.05)$. The Tukey test with a $5 \%$ probability was used to analyze the experimental data using SISVAR software (FERREIRA, 2011).

\section{RESULTS AND DISCUSSION}

During collection, it was noted that the typic dystrophic Red Oxisol soil was the first soil to finish the process, indicating that solution infiltration in this soil type is faster compared with the other studied soils. The collection conclusion sequence from fastest to slowest was: typic dystrophic Red Oxisol, Entisol Quartzipsamment, and Eutrophic Cambisol.

The ion movement in each soil can be explained by their specific parameters. Araujo et al. (2000) reinforced the idea that the application of this technique to study ion movement in soil contributes to a more rational fertigation use, including using elements with low mobility. Santos et al. (2010b) found that the lower the solution advance speed in the soil column, the greater the contact time was between the ions and the soil colloids, providing 
greater opportunities for solute retention and causing an increase in the retardation factor. For potassium ions $\left(\mathrm{K}^{+}\right)$(Fig. 2), the sigmoidal behavior was slightly different in the Eutrophic Cambisol soil, wherein it had a marked peak rise compared with the other studied soils. According to Araújo et al. (2000), this may occur due to the low cation adsorption capacity of this material. Araújo et al. (2000) reported that during displacement, the potassium shifter fluid was attracted by the colloids, displacing the calcium, which accompanied the phosphate and thus keeping the system electrostatically constant.

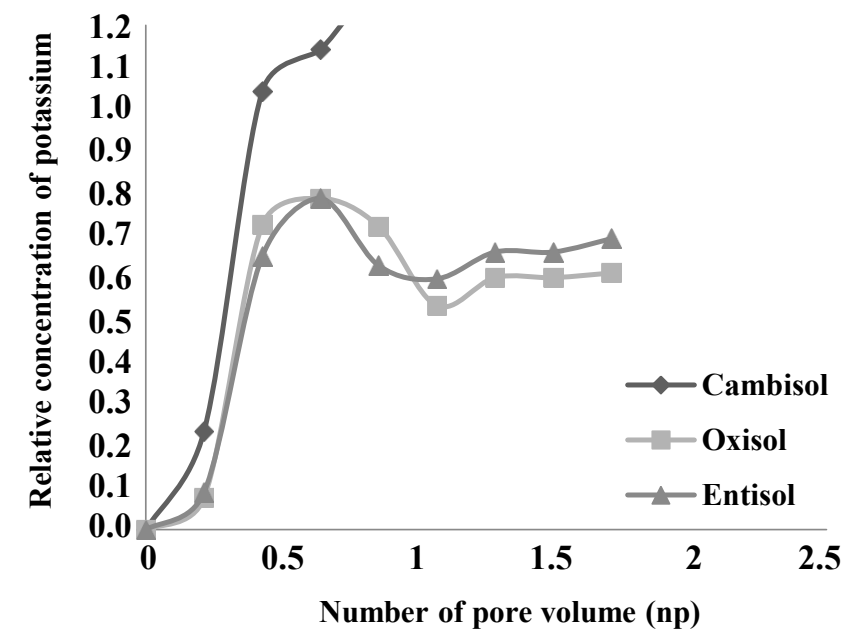

Figure 2. Relationships between relative concentration potassium and number of pore volume as influenced by Soil texture

Melo et al. (2006) emphasized in his work on the miscible displacement of basic cations from manioc waste-water in soil columns that the retardation factor, being a characteristic that portrays the soils ability to retain solutes to the extent that the mass flow advances, depends on the interactions between the liquid and solid phases occurring during percolation.
It was observed that the retardation factor ranged from 0.28 to 0.37 for the potassium ions in the studied soils. This parameter was similar for Eutrophic Cambisol and typic dystrophic Red Oxisol; however, the value was statistically higher in Entisol Quartzipsamment, with an R-value of to 0.37 (Table 6).

Table 6. Potassium ion $\left(\mathrm{K}^{+}\right)$parameters for the three soils.

\begin{tabular}{ccc}
\hline Soil & $\mathrm{R}$ (retardation) & $\mathrm{D}$ (diffusion-dispersion) \\
\hline & & $\left(\mathrm{cm}^{2} \mathrm{~h}^{-1}\right)$ \\
Eutrophic Cambisol & $0.28 \mathrm{~b}$ & $45.90 \mathrm{a}$ \\
typic dystrophic Red Oxisol & $0.35 \mathrm{~b}$ & $127.76 \mathrm{~b}$ \\
Entisol Quartzipsamment & $0.37 \mathrm{a}$ & $103.40 \mathrm{c}$ \\
\hline
\end{tabular}

The dispersion-diffusion coefficient (D) varied from 45.90 to $127.76 \mathrm{~cm}^{2} \mathrm{~h}^{-1}$. This parameter was significantly different for each soil, which implies that the potassium displacement is variable in each soil and is smaller in Eutrophic Cambisol and larger in typic dystrophic Red Oxisol (Table 6).

The Eutrophic Cambisol had a higher degree of soil profile $\mathrm{K}^{+}$contamination when subjected to the saline tailings due to the low ion mobility, as verified by the $\mathrm{D}$ value, whereas the typic dystrophic Red Oxisol presented a lower degree of soil contamination but a greater degree of groundwater contamination. As the retardation factors of Eutrophic Cambisol and typic dystrophic Red Oxisol were statistically superior to that of Entisol Quartzipsamment, lower retention of this ion was observed in this soil, which is attributable to the higher sand fraction content in the soil.

For the sodium ion $\left(\mathrm{Na}^{+}\right)$(Fig. 3), sigmoidal behavior was observed for the studied soils with a slight stability oscillation for the Eutrophic Cambisol. 


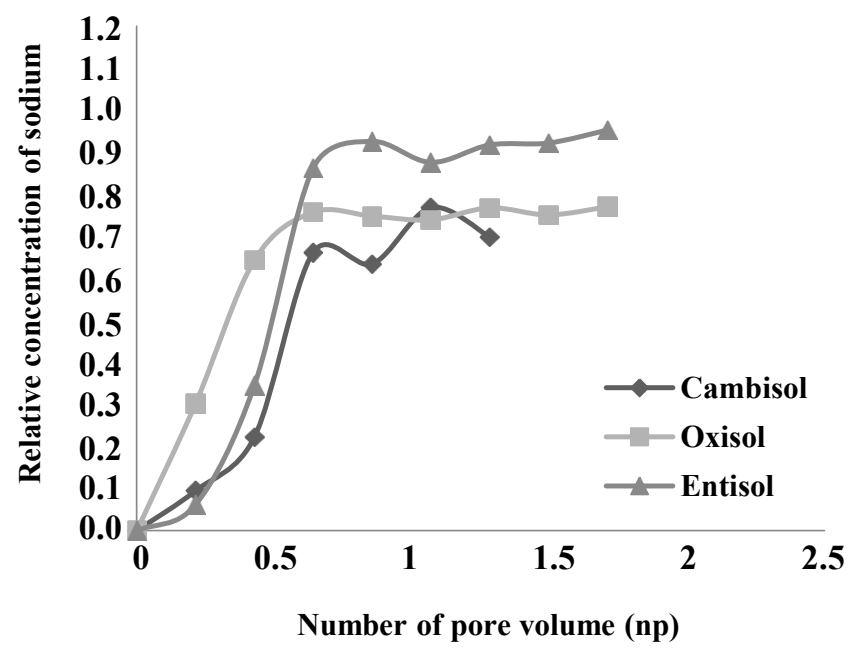

Figure 3. Relationships between relative concentration of sodium and number of pore volume as influenced by Soil textures.

Table 7 indicates that the retardation factor for $\mathrm{Na}^{+}$was significantly different between all studied soils: this parameter was highest in Eutrophic Cambisol and lowest in typic dystrophic Red Oxisol. The $\mathrm{Na}^{+}$had a larger degree of contamination in Eutrophic Cambisol, while typic dystrophic Red Oxisol was less contaminated by this ion. This can be explained by comparing these results to the work by Messias et al. (2006) on Na percolation through the soils in the state of Pernambuco, where it was observed that for the argillaceous soil, there was a greater dispersion in the distribution as a function of time, thus characterizing a delay in sodium percolation.

Table 7. Sodium ion $\left(\mathrm{Na}^{+}\right)$parameters for the three soils.

\begin{tabular}{ccc}
\hline Soil & R (retardation) & D (diffusion-dispersion) \\
\hline & & $\left(\mathrm{cm}^{2} \mathrm{~h}^{-1}\right)$ \\
Eutrophic Cambisol & $0.56 \mathrm{a}$ & $29.85 \mathrm{c}$ \\
typic dystrophic Red Oxisol & $0.34 \mathrm{c}$ & $403.09 \mathrm{a}$ \\
Entisol Quartzipsamment & $0.50 \mathrm{~b}$ & $197.29 \mathrm{~b}$ \\
\hline
\end{tabular}

The diffusion-dispersion coefficient (Table 7) was also significantly different in all soils. This implies that in each soil, $\mathrm{Na}$ displacement is variable, being highest for typic dystrophic Red Oxisol.
The chloride ion $\left(\mathrm{Cl}^{-}\right)$(Fig. 4) presented the best sigmoidal behavior for all ions in the studied soils. We notice that the analyzed soils followed the same trend line on the curve.

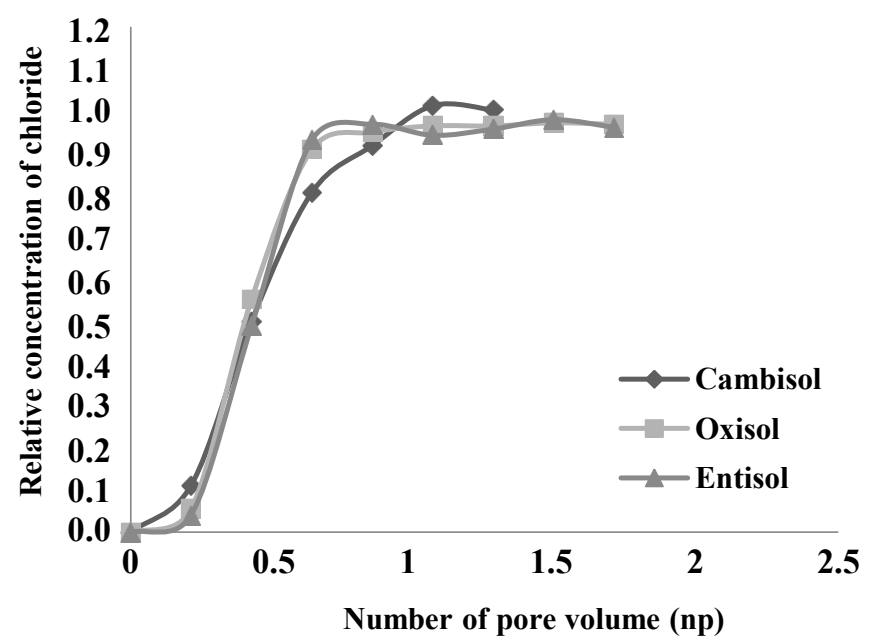

Figure 4. Relationships between relative concentration of chloride and number of pore volume as influenced by Soil textures. 
The retardation factor of $\mathrm{Cl}^{-}$was statistically similar in Eutrophic Cambisol and Entisol Quartzipsamment, but different in typic dystrophic
Red Oxisol, with higher values of this ion found in Eutrophic Cambisol and Entisol Quartzipsamment (Table 8).

Table 8. Chloride ion $\left(\mathrm{Cl}^{-}\right)$parameters for the three soils.

\begin{tabular}{ccc}
\hline Soil & $\mathrm{R}$ (retardation) & $\mathrm{D}$ (diffusion-dispersion) \\
\hline & & $\left(\mathrm{cm}^{2} \mathrm{~h}^{-1}\right)$ \\
Eutrophic Cambisol & $0.42 \mathrm{a}$ & $89.69 \mathrm{c}$ \\
typic dystrophic Red Oxisol & $0.40 \mathrm{~b}$ & $623.70 \mathrm{a}$ \\
Entisol Quartzipsamment & $0.42 \mathrm{a}$ & $109.22 \mathrm{~b}$ \\
\hline
\end{tabular}

The soils studied had significantly different D values. This parameter was highest for typic dystrophic Red Oxisol, which suggests that the $\mathrm{Cl}$ displacement varies in each soil. According to the D value for the chloride ion, the Eutrophic Cambisol soil had the greatest degree of contamination, while the typic dystrophic Red Oxisol experienced the least contamination.

\section{CONCLUSIONS}

There were differences in the ion displacement curves present in the saline waste among the studied soils types, with distinct contamination potential on the surface and the subsurface.

Entisol Quartzipsamment had the highest speed of $\mathrm{K}^{+}$and $\mathrm{Cl}^{-}$ions (retardation factor), that is, the greatest degree of contamination in the subsurface with these ions. Regarding the dispersiondiffusion coefficient, for typic dystrophic Red Oxisol, the ions moved more easily and increased the possibility of groundwater contamination.

Eutrophic Cambisol was found to have a low diffusion-dispersion coefficient in all evaluated ions and thus lower ion mobility in the soil profile.

\section{REFERENCES}

ABAS - Associação Brasileira de Águas Subterrâneas. Água subterrânea: Minimização das consequências da seca no Nordeste. 1. ed. São Paulo, SP: ABAS, 2003. 37 p.

ARAÚJO, C. A. S. et al. Transporte de fósforo e de potássio em colunas com agregados de um Latossolo vermelho distrófico. Revista Brasileira de Ciência do Solo, Viçosa, v. 24, n. 2, p. 259-268, 2000.

AYRES, R. S.; WESTCOT, D. W. A qualidade da água na agricultura. Tradução de Gheyi, H. R.; Medeiros, J. F.; Damasceno, F. A. V. 2.ed. Campina Grande: UFP, 1999. 153 p. (Estudos FAO Irrigação e Drenagem, 29)
BORGES JUNIOR, J. C. F.; FERREIRA, P. A Equações e programa computacional para cálculo do transporte de solutos no solo. Revista Brasileira de Engenharia Agrícola e Ambiental, Campina Grande, v. 10, n. 3, p. 604-611, 2006.

COSME, C. R. et al. Produção de tomate hidropônico utilizando rejeito da dessalinização na solução nutritiva aplicados em diferentes épocas. Revista Brasileira de Engenharia Agrícola e Ambiental, Campina Grande, v. 15, n. 5, p. 499-504, 2011 .

DIAS, N. S. et al. Uso de rejeito da dessalinização na solução nutritiva da alface, cultivada em fibra de coco. Revista Ceres, Viçosa, v. 58, n. 5, p. 632-637, 2011a.

DIAS, N. S. et al. Produção de melão rendilhado em sistema hidropônico com rejeito da dessalinização de água em solução nutritiva. Revista Brasileira de Engenharia Agrícola e Ambiental, Campina Grande, v. 14, n. 1, p. 755-761, 2010.

DIAS, N. S. et al. Resposta de cultivares de alface à salinidade da solução nutritiva com rejeito salino em hidroponia. Revista Brasileira de Engenharia Agrícola e Ambiental, Campina Grande, v. 15, n. 10, p. 991-995, 2011 b.

EMBRAPA, Empresa Brasileira de Pesquisa Agropecuária. Manual de métodos de análise de solo. 2. ed. Rio de Janeiro, RJ: Embrapa, 1997. 212 p.

FERREIRA, D. F. Sisvar: a computer statistical analysis system. Ciência e Agrotecnologia, Lavras, v. 35 , n. 6 , p. 1039-1042, 2011.

GOMES, J. W. S. et al. Crescimento e produção de tomate cereja em sistema hidropônico com rejeito de dessalinização. Revista Ciência Agronômica, Fortaleza, v. 42, n. 4, p. 850-856, 2011.

HESPANHOL, I. Potencial de reuso de água no Brasil: Agricultura, indústria, municípios, recarga de aquíferos. Revista Brasileira de Recursos Hídricos, Campina Grande, v. 7, n. 4, p. 75-95, 
2002.

MEDEIROS, J. F. et al. Caracterização das águas subterrâneas usadas para irrigação na área produtora de melão da chapada do Apodi. Revista Brasileira de Engenharia Agrícola e Ambiental, Campina Grande, v. 7, n. 3, p. 469-472, 2003.

MELO, R. F. M. et al. Deslocamento miscível de cátions básicos provenientes da água residuária de mandioca em colunas de solo. Revista Brasileira de Engenharia Agrícola e Ambiental, Campina Grande, v. 10, n. 7, p. 456-465, 2006.

MESSIAS, A. S. et al. Percolação de sódio através de solos do Estado de Pernambuco, Brasil. Revista de Biologia e Ciências da Terra, Campina Grande, v. 2 , n. 1 , p. 65-72, 2006.

OLIVEIRA, A. M. P. Mobilização de íons em solos tratados com rejeito da dessalinização por osmose reversa. 2012. 47 f. Dissertação (Mestrado em Irrigação e Drenagem: Área de concentração em Impactos Ambientais pelo Uso da Água) Universidade Federal Rural do Semi-Árido, Mossoró, 2012.

OLIVEIRA, B. C. et al. Características produtivas do tomateiro submetido a diferentes níveis de sais, na água de irrigação. Revista Brasileira de Engenharia Agrícola e Ambiental, Campina Grande, v. 11, n. 1, p. 11-16, 2007.

PORTO, E. R. Uso do rejeito da dessalinização de água salobra para irrigação da erva-sal (Atriplex nummularia). Revista Brasileira de Engenharia Agrícola e Ambiental, Campina Grande, v. 5, n. 1, p. 111-114, 2001.

SANTOS, A. N. et al. Produção de alface em NFT e Floating aproveitando água salobra e o rejeito da dessalinização. Revista Ciência Agronômica, Fortaleza, v. 2, n. 1, p. 319-326, 2011.

SANTOS, A. N. et al. Cultivo hidropônico de alface com água salobra subterrânea e rejeito da dessalinização em Ibimirim, PE. Revista Brasileira de Engenharia Agrícola e Ambiental, Campina Grande, v. 14, n. 11, p. 961-969, 2010a.

SANTOS, J. S. et al. Mobilidade de solutos em colunas de solo com água residuária doméstica e de suinocultura. Revista Brasileira de Engenharia Agrícola e Ambiental, Campina Grande, v. 14, n. 11, p. 1226-1233, 2010b.

SANTOS, R. S. S. et al. Uso do rejeito da dessalinização de água salobra no cultivo da alface (Lactuca sativa L.) em sistema hidropônico NFT.

Ciência e Agrotecnologia, Lavras, v. 34, n. 4, p. 983
$-989,2010 c$.

SCHNEIDER, R. T.; TSUTIYA, M. T. Membranas filtrantes para o tratamento de água, esgoto e águas de reuso. 1. ed. São Paulo, SP: ABAS, 2001. 234 p.

SILVA, A. O. et al. Produção de rúcula em sistema hidropônico NFT utilizando água salina do Semiárido - PE e rejeito de dessalinizador. Revista Brasileira de Ciências Agrárias, Recife, v. 6, n. 1, p. 147-155, 2011.

SILVA, C. M. M. S.; VIEIRA, R. F.; OLIVEIRA, P. R. Salinidade, sodicidade e propriedades microbiológicas de Argissolo cultivado com erva-sal e irrigado com rejeito salino. Pesquisa Agropecuária Brasileira, Brasília, v. 43, n. 10, p. 1389-1396, 2008.

SOARES, T. M. et al. Destinação de águas residuárias provenientes do processo de dessalinização por osmose reversa. Revista Brasileira de Engenharia Agrícola e Ambiental, Campina Grande, v. 10, n. 3, p. 730-737, 2006.

SOUSA NETO, O. N. et al. Utilização do rejeito da dessalinização da água na produção de mudas de espécies da Caatinga. Revista Caatinga, Mossoró, v. 24, n. 4, p. 123-129, 2011.

TEDESCO, M. J. et al. Análise de solo, plantas e outros materiais. 2. ed. Porto Alegre, RS: UFRGS, 1995. 174 p.VOUTCHKOV, N. The ocean: A new resource for drinking water. [S.1.], Public Works, 2004. 30 p. 